Ks. Piotr SZCZUR*

\title{
CZY DUSZA WALCZY Z CIAŁEM? Wybrane aspekty antropologii św. Jana Chryzostoma
}

We współczesnym świecie spotyka się mnogość różnych ujęć antropologicznych, usiłujących ukazać człowieka w rozmaitych jego wymiarach. Jednak szczególne miejsce należy przypisać antropologii chrześcijańskiej, którą można w pełni zrozumieć tylko dzięki poznaniu Jezusa Chrystusa i zjednoczeniu się z Nim, co już przed laty zostało wyrażone w nauczaniu i świadectwie Ojców Kościoła. Czerpanie z ich myśli jest potrzebne szczególnie dziś, w dobie pluralizmu antropologicznego. Z tego powodu w niniejszym artykule postanowiono zająć się nauczaniem jednego z czterech wielkich doktorów Kościoła Wschodniego - Jana Chryzostoma, na temat wzajemnych relacji duszy i ciała. Bazę źródłową będą stanowiły wypowiedzi złotoustego kaznodziei zawarte przede wszystkim w homiliach na listy św. Pawła oraz Księgę Rodzaju, a także na Ewangelie, Dzieje Apostolskie i Księgę Psalmów ${ }^{1}$. W artykule zostaną omówione kolejno takie zagadnienia jak sytuacja człowieka po grzechu pierworodnym, relacja pomiędzy duszą i ciałem, nieśmiertelność duszy oraz jej godność i pierwszeństwo przed ciałem, a także relacja życia biologicznego ciała do życia duchowego duszy i ,walka” duszy z ciałem.

1. Ciało czlowieka po grzechu pierworodnym w perspektywie eschatologicznej. Pobieżna analiza opisu sceny grzechu pierworodnego (por. Rdz 3, 1-24) mogłaby prowadzić do wniosku, że upadek prarodziców - Adama i Ewy - stworzył nową sytuację korzystną dla rozkwitu grzechu i nieprawości. Jednak taka sytuacja byłaby możliwa tylko wówczas, gdyby rozpatrywało się sytuację człowieka po grzechu pierworodnym w oderwaniu od mądrości Boga i Jego miłości do człowieka ( $\left.\varphi \imath \lambda \alpha \nu \theta \rho \omega \pi i \alpha^{2}\right)$. W rzeczywistości człowiek ,skorzystał" na konsekwencjach upadku, lub raczej skorzystał z terapeutycznych

* Ks. dr hab. Piotr Szczur, prof. KUL - kierownik Katedry Historii Kościoła w Starożytności i Średniowieczu w Instytucie Historii Kościoła i Patrologii na Wydziale Teologii Katolickiego Uniwersytetu Lubelskiego Jana Pawła II; e-mail: p.szczczur@kul.pl.

${ }^{1}$ Przede wszystkim korzystano w wydań opublikowanych w przez Jeana Paula Migne'a w: $P a-$ trologia cursus completus. Series Graeca oraz z istniejących wydań krytycznych opublikowanych w serii „Sources Chrétiennes”.

2 Termin $\varphi \imath \lambda \alpha \nu \theta \rho \omega \pi i \alpha$ przyjmuje następujące znaczenia: „ludzkość, życzliwość, ludzkie uczucia; stosunki wzajemne kochanków; pl. akty uprzejmości, grzeczności; miłość Boga do lu- 
środków, jakie Bóg dał po upadku prarodziców, aby zapewnić mu swego rodzaju środowisko pedagogiczne, w jakie miał wkroczyć i, co więcej, aby odnieść korzyść z istnienia i obecności w świecie. W rzeczywistości, rozpowszechnienie się zła i grzechu oraz królestwa szatana, nie tworzy samo w sobie formy nacisku zmuszającej człowieka do czynienia zła, gdyż grzech jest konsekwencją wolnego wyboru człowieka. Jan Chryzostom w swym nauczaniu przyjmuje tę właśnie perspektywę historiozbawczą i broni absolutnej wolności człowieka zarówno przed, jak i po upadku. Co więcej, podkreśla, że dzięki wolności człowiek może dążyć do doskonałości i jedności z Bogiem. Jan Chryzostom uważa, że ciało $\left(\sigma \hat{\omega} \mu \alpha^{3}\right)$ po upadku człowieka nie może być uważane za element skłaniający istotę ludzką do grzechu. Wprawdzie Apostoł Paweł opisuje ciało jako grzeszne (por. Rz 6, 6), śmiertelne (por. Rz 6, 12; 2 Kor 5,4$)$, itd. Jednak tych określeń nie należy rozumieć i interpretować jako rodzaj ,zarzutów” wobec ciała, lecz należy je postrzegać przez pryzmat eschatologicznego tła wypowiedzi Apostoła Narodów. Przykładowo, kiedy św. Jan Chryzostom objaśnia wypowiedź św. Pawła: „Niechże więc grzech nie króluje w waszym śmiertelnym ciele" (Rz 6, 12), wyraźnie stwierdza, że Apostoł nie oskarża śmiertelnego ciała o to, że jest przyczyną grzechu, lecz stara się pocieszyć odbiorców listu, aby nie załamali się z powodu konieczności prowadzenia walki z grzechem, gdyż walka ta jest ograniczona do doczesności, a zwycięstwo w gruncie rzeczy jest łatwe.

„Następnie, ponieważ trudno jest zwyciężać grzech, przypatrz się jak [Paweł] unaocznił łatwość tego i złagodził trud, mówiąc: «W waszym śmiertelnym ciele» (Rz 6, 12). Wyraża to, że walki są doczesne i wnet się skończą"4.

Należy zwrócić uwagę na fakt, że św. Paweł w zacytowanej wypowiedzi używa terminu ,śmiertelny" ( $\left.\theta v \eta \tau \iota^{5} \varsigma^{5}\right)$ zarówno w jego konotacji doczesnej, jak i eschatologicznej. W rzeczywistości Paweł zamierzał powiedzieć: „ta śmiertelność, jako stan, osiagnie swój kres”. Jest to stwierdzenie, które dodaje odwagi, wznieca zapał oraz napełnia nadzieją człowieka gdy znosi trudy „doczesnej walki", i tym samym sprawia, że zwycięstwo staje się łatwiejszym zadaniem $^{6}$. Grzech panuje nie tylko przez śmiertelne ciało, ale także przez gnuśność. Wydaje się, że takie jest właściwe znaczenie słów Pawła: „poddając

\footnotetext{
dzi” (Abramowiczówna IV 515-516, s.v. $\varphi \imath \lambda \alpha \nu \theta \rho \omega \pi i \alpha)$. Podobne znaczenia podają również inne słowniki, por. Lampe, s. 1475-1476, s.v. $\varphi \imath \lambda \alpha \nu \theta \rho \omega \pi i \alpha$; Liddell - Scott, s. 1932, s.v. $\varphi \imath \lambda \alpha v \theta \rho \omega ́-$ $\pi \varepsilon v \mu \alpha\left(\varphi \imath \lambda \alpha \theta \rho \omega \pi^{\prime} \alpha\right)$.

${ }^{3}$ Por. Abramowiczówna IV 267, s.v. $\sigma \hat{\omega} \mu \alpha$; Lampe, s. 1362-1366, s.v. $\sigma \hat{\omega} \mu \alpha$; Liddell - Scott, s. 1749 , s.v. $\sigma \hat{\omega} \mu \alpha$.

${ }^{4}$ Joannes Chrysostomus, In Epistulam ad Romanos hom. 11, 2, PG 60, 486, thum. Sinko: Św. Jan Chryzostom, Homilie na List św. Pawła do Rzymian, oprac. A. Baron, t. 1, Kraków 1995, 164.

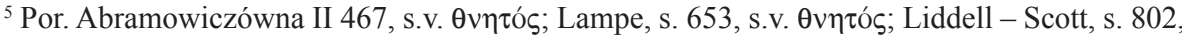

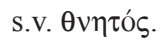

${ }^{6}$ Por. Joannes Chrysostomus, In Epistulam ad Romanos hom. 11, 2-3, PG 60, 486-487.
} 
was swoim pożądliwościom [w waszym śmiertelnym ciele]'. Przez te wyrażenia św. Paweł wyraźnie wskazuje, że ,ciało zajmuje miejsce pośrodku między

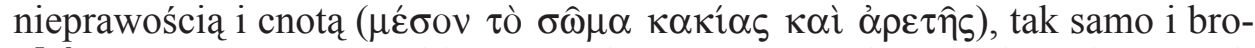
ń$^{798}$. Wyjaśniając ten problem Jan Chryzostom przedstawia dwa obrazy: odwołuje się do posługiwania się bronią i oczami oraz innymi członkami ciała:

„Rzecz ma się tak, jak gdyby żołnierz walczący za ojczyznę i rabuś uzbrojony przeciw mieszkańcom byli zbrojni w ten sam oręż; nie jest to wina uzbrojenia, lecz tych, którzy go używają w złym celu. Można to powiedzieć także o ciele, które staje się tym czy tamtym stosownie do woli duszy, a nie według własnej natury9 ${ }^{9}$. Jeśli więc patrzysz niepotrzebnie na cudzą piękność, oko staje się orężem niesprawiedliwości, nie z własnej zdolności działania, (gdyż przeznaczeniem oka jest widzieć, nie zaś źle widzieć), lecz z nieprawości rozkazującego rozumu. Jeśli zaś je okiełznasz, staje się orężem sprawiedliwości. Tak jest i z językiem, i z rękami, i z wszystkimi innymi członkami"10.

Uzbrojenie wykorzystuje się do walki, która może być prowadzona w sprawie słusznej lub niesłusznej. Podobnie oko jest narządem receptorowym umożliwiającym widzenie - jego zadaniem jest, aby coś zobaczyć, ale widząc można obrać dobry lub zły kierunek, a to już jest dziełem woli człowieka, a nie oka. W tej samej perspektywie, należy rozumieć słowa św. Pawła: „To wiedzcie, że dla zniszczenia grzesznego ciała dawny nasz człowiek został razem z nim ukrzyżowany" (Rz 6, 6), które komentując Jan Chryzostom wyjaśnia, że pojęcie „ciało” $(\sigma \hat{\omega} \mu \alpha)$ użyte w tym kontekście przez Apostoła nie oznacza materialnego ciała człowieka, lecz wszelką nieprawość:

„Dlatego [Paweł] wcześniej powiedział: «Jesteśmy zrośnięci z podobieństwem jego śmierci, aby zniszczone zostało ciało grzechu» ( $\mathrm{Rz} 6,6)$, nie

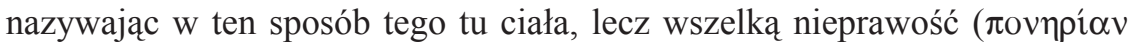

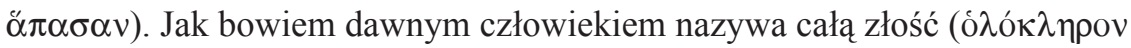

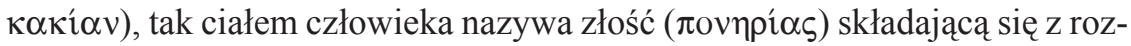

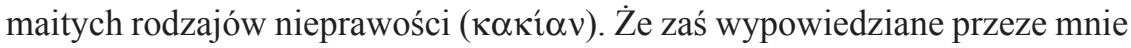
słowa nie są moim domysłem, posłuchaj, jak to sam Paweł w dalszym ciągu tłumaczy. Powiedziawszy: «aby zniszczone zostało ciało grzechu», dodał: «i abyśmy nie służyli dłużej grzechowi» (Rz 6, 6). Chcę bowiem, aby

${ }^{7} \mathrm{~W}$ tym miejscu dokonano korekty przekładu polskiego, gdyż Jan Chryzostom używa tu terminu ö $\pi \lambda \alpha$, który jest formą rzeczownika ö $\pi \lambda$ ov. Rzeczownik ten przyjmuje m.in. następujące znaczenia: „narzędzie; 1. sprzęt okrętowy, osprzęt; 2. narzędzia, zwt. kowalskie; 3. zbroja, uzbrojenie, oręż i pancerz” (Abramowiczówna III 300-301). Zaproponowane przez T. Sinko słowo „narzędzia” zastąpiono terminem „broń”, gdyż w dalszej części wypowiedzi Chryzostom nawiązuje do żołnierzy i ich uzbrojenia.

${ }^{8}$ Joannes Chrysostomus, In Epistulam ad Romanos hom. 11, 3, PG 60, 487, thum. Sinko, t. 1, s. 165.

${ }^{9}$ Por. Aristoteles, Magna moralia I 1183b; postępowanie zależy od woli człowieka, por. tamże $1187 \mathrm{~b} ; 1188 \mathrm{~b}$.

${ }^{10}$ Joannes Chrysostomus, In Epistulam ad Romanos hom. 11, 3, PG 60, 487, thum. Sinko, t. 1, s. 165. 
ciało było martwe dla grzechu, nie tak, żeby zniszczało i zmarło, lecz żeby nie grzeszyło" $"$.

Św. Paweł również to samo ma na uwadze, gdy mówi o konieczności „zniszczenia grzesznego ciała” (Rz 6, 6), aby ,stary człowiek ( $\pi \alpha \lambda \alpha i o ̀ \varsigma ~ \alpha ้ \nu \theta \rho \omega \pi \circ \varsigma)$ )" (por. Rz 6, 6; Ef 4, 22; Kol 3, 9) został „ukrzyżowany”, czyli uśmiercony. Tych wskazań Apostoła Narodów nie wolno interpretować w sposób dosłowny, gdyż Paweł nie wzywa do zadawania śmierci ciału, lecz do uśmiercania wszelkiej nieprawości, którą określa w taki właśnie sposób.

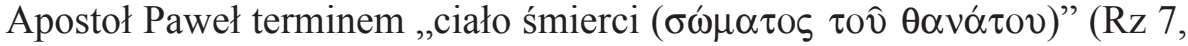
24) określa również materialne ciało człowieka, jednak przez to sformułowanie nie wskazuje, że ciało powoduje śmierć, lecz że śmierć ostatecznie ,zdobędzie" ciało. Przez pryzmat tego wyrażenia św. Jan Chryzostom interpretuje słowa Pawła z Drugiego Listu do Koryntian $(5,4)$ mówiące o przyodzianiu ciała nowym odzieniem, i podkreśla, że ciało nie jest złe oraz że Paweł ma na myśli nie tylko materialne ciało. W rzeczywistości Apostołowi Narodów chodziło o duchowe zepsucie poprzez grzech i przeciwstawienie się temu zepsuciu, czyli wszelkiej nieprawości. Kaznodzieja zaznacza, że wprawdzie z jednej strony człowiek , ,jęczy” z powodu sposobu, w jaki zostanie uwolniony z ciała, jednak z drugiej strony nie może się doczekać uwolnienia od zepsucia, które jest w jego wnętrzu ${ }^{12}$. W ten sposób Chryzostom przedstawia eschatologiczną interpretację faktu, że Apostoł Paweł nie odrzuca ciała, ale narzeka na jego podatność na zepsucie i pragnie życia doczesnego (,,aby to, co śmiertelne [tj. zepsucie] wchłonięte zostało przez życie", 2Kor 5, 4). Według św. Jana Chryzostoma, Paweł Apostoł nie może doczekać się ujrzenia eschatologicznej formy ciała pozbawionego zepsucia i chwili, gdy będzie ją mógł przywdziać. Jeśli jednak tymczasem narzeka, to tylko z powodu obecnej sytuacji, która jest nieudolną imitacją prawdziwego piękna i alienacją od Boga, gdyż Bóg stworzył człowieka nie po to, aby pozostawić go na pastwę śmierci, ale żeby uczestniczył w nieśmiertelności ${ }^{13}$. Kiedy zaś Paweł mówi: „Pokarm dla żołądka, a żołądek dla pokarmu. Bóg zaś unicestwi jedno i drugie" (1Kor 6, 13), nie potępia ciała, ale odnosi się do stanu eschatologicznego, kiedy człowiek nie będzie ani jadł, ani pił, i kiedy zostaną przezwyciężone wszelkie słabości i potrzeby ciała. W tych słowach - jak mówi Chryzostom - Paweł potępia niewłaściwe pragnienia duszy, a nie ciała. Ponadto, św. Jan Chryzostom zauważa, że Paweł Apostoł dalej mówi, iż ,ciało nie jest dla rozpusty, lecz dla Pana” (1Kor $6,13)^{14}$. Zaś komentując werset z Listu do Rzymian $(7,5)$ mówi:

\footnotetext{
${ }^{11}$ Tamże 11, 1, PG 60, 485, thum. Sinko, t. 1, s. 162-163.

${ }^{12}$ Por. tenże, In Epistulam II ad Coronthios hom. 10, 1-2, PG 61, 468.

${ }^{13}$ Por. tamże 10, 2, PG 61, 468.

${ }^{14}$ Por. tenże, In Epistulam I ad Coronthios hom. 17, 1, PG 61, 140.
} 
„[Paweł] nie chcąc oskarżać ciała, nie powiedział, że członki pobudzały grzeszne namiętności, lecz one działały w naszych członkach, wskazując, że

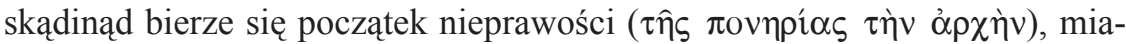

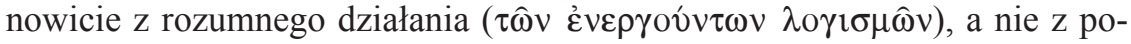

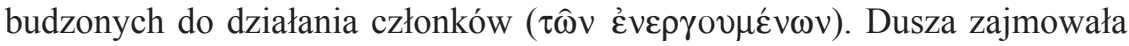
przy tym miejsce artysty, a ciało - cytry, która wydaje takie tony, do jakich ja zmusza artysta. Nie jej więc powinniśmy przypisywać źle brzmiącą melodię, lecz raczej tamtej [tj. duszy]"15.

Zatem ciało, chociaż jest grzeszne, nie ponosi odpowiedzialności za grzechy człowieka, gdyż grzech rodzi się w rozumnej duszy, podobnie jak za nieczystą melodię ponosi odpowiedzialność artysta, a nie instrument muzyczny, na którym muzyk gra. Z powyższych analiz jasno wynika, że św. Jan Chryzostom poprzez eschatologiczne ukierunkowanie interpretacji wypowiedzi Apostoła Pawła, obala błędne rozumienie zasadniczych treści myśli Pawłowej na temat ciała.

2. Relacja pomiędzy ciałem a duszą. Dla św. Jana Chryzostoma relacja pomiędzy ciałem a duszą może być porównana do relacji pomiędzy jeźdźcem a koniem ${ }^{16}$, albo pomiędzy panią i służącą ${ }^{17}$, ewentualnie cytrą i cytrzystą (o czym bała już mowa powyżej) lub okrętem i kapitanem:

„My zaś przyznajemy, że ciało jest niższe od duszy i mniej doskonałe, jednak nie wrogie jej, ani nie walczące z nią, ani złe, lecz że tak podlega duszy, jak cytra cytrzyście ${ }^{18}$ i jak okręt sternikowi, które nie są przeciwne prowadzącym je i używającym ich, ale nawet pozostają z nimi w wielkiej harmonii, tylko że nie mają równej wartości z mistrzem. Jak więc ten, kto mówi: «Nie w cytrze i nie w okręcie tkwi sztuka, lecz w sterniku i cytrzyście», wcale nie uwłacza tamtym rzeczom, lecz wskazuje, jak wielka jest różnica pomiędzy mistrzem a [jego] dziełem. Tak Paweł mówiąc: «W moim ciele nie mieszka dobro» nie ubliżył ciału, lecz wskazał na wyższość duszy nad nim. Duszy bowiem poruczona jest całość sterowania i gry na cytrze. To właśnie wykazuje tu Paweł, przyznając władzę duszy. Dzieląc zaś człowieka na dwa składniki: duszę i ciało, mówi, że ciało jest wprawdzie mniej rozumne, pozbawione rozsądku, poddane działaniu, a nie działające, dusza zaś [jest] rozumniejsza i zdolna ocenić, co należy czynić, a czego nie, ale nie jest w stanie kierować rumakiem ${ }^{19}$

${ }^{15}$ Tenże, In Epistulam ad Romanos hom. 12, 3, PG 60, 498, thum. Sinko, t. 1, s. 180.

${ }^{16}$ Por. tenże, In Acta Apostolorums hom. 29, 4, PG 60, 220.

${ }^{17}$ Por. tenże, In Matthaeum hom. 55, 4, PG 57, 544.

${ }^{18}$ Por. tenże, In Epistulam ad Romanos hom. 12, 3, PG 60, 498, gdzie złotousty kaznodzieja używa tego samego przykładu, lecz mniej rozbudowanego.

${ }^{19}$ Por. Plato, Phaedrus 245C; Joannes Chrysostomus, In Epistulam ad Romanos hom. 12, 3, PG 60, 498-499, tłum. Sinko, t. 1, s. 181: „Otóż, powiada, kiedy Adam zgrzeszył, a ciało jego stało się śmiertelne, podległe cierpieniom i poniosło wiele naturalnych szkód, koń stał się cięższy i trudny 
podług swej woli. A taki stan byłby winą nie tylko ciała, lecz i duszy, która wie, co należy czynić, lecz nie przemienia w czyn swych postanowień"

Jan Chryzostom używając wyżej wymienionych porównań, przenosi na duszę odpowiedzialność za czyny ciała. W ten sposób nadaje duszy większą wagę w porównaniu $z$ ciałem, a tym samym ciało okazuje się być niżej postawione od duszy. Nie znaczy to jednak, że ciało i dusza toczą ze sobą walkę. Przeciwnie, wymienione porównania akcentują harmonię i wzajemną odpowiedzialność, co można dostrzec na przykładzie cytry i muzyka grającego na niej, albo okrętu i jego kapitana. W konsekwencji, bezużyteczne jest dbanie o ciało, kiedy zaniedbuje się duszę. Odnosząc się do tego odwrócenia hierarchii wartości, św. Jan Chryzostom thumaczy, że w takiej sytuacji dzieje się to, co można obserwować, kiedy dobra zabawa i odpoczynek służącej nie przynoszą żadnej korzyści konającej pani:

„Jeśli twoje ciało jest tuczone, a dusza usycha, to nie wynika dla ciebie żadna korzyść z takiej obfitości, tak samo jak wtedy, gdy raduje się niewolnica, na nic nie przyda się ginącej pani radość tej służebnicy ani ozdobna suknia choremu ciału, lecz znów powie ci Chrystus: «Co da człowiek w zamian za swoją duszę?» (Mt 16, 26), nakazując ci, byś zawsze i wszędzie troszczył się o swą duszę i myślał tylko o niej”"21.

Złotousty kaznodzieja chcą uzmysłowić słuchaczom swoich homilii znaczenia duszy odwołuje się do wypowiedzi Pawła Apostoła z Pierwszego Listu do Koryntian (5, 1-5), który chcąc ratować duszę cudzołożnika (a być może nawet kazirodcy) z Koryntu polecił wspólnocie Kościoła: ,wydajcie takiego szatanowi na zatracenie ciała, lecz ku ratunkowi jego ducha w dzień Pana Jezusa" $(1 \text { Kor } 5,5)^{22}$. Podobnym przykładem, do którego czyni odniesienia, jest postać Hioba $^{23}$. Natomiast w 15. Homilii na Pierwszy List do Koryntian naucza, że ciało cierpi z powodu grzechu duszy, natomiast jeśli dusza będzie postępowała sprawiedliwie, to również ciało będzie uczestniczyć w chwale duszy ${ }^{24}$.

Oczywiście człowiek jest bytem psychosomatycznym, w którym ciało jest postrzegane jako instrument duszy ${ }^{25}$. Jednak, można się zastawiać, do jakiego

do okiełznania. Przyszedł jednak Chrystus i uczynił go lżejszym dla nas przez chrzest, pobudzając go skrzydłem Ducha".

${ }^{20}$ Joannes Chrysostomus, In Epistulam ad Romanos hom. 13, 2, PG 60, 509-510, thum. Sinko, t. 1 , s. 196.

${ }^{21}$ Tenże, In Matthaeum hom. 55, 4, PG 57, 544, ŹMT 22, 163-164.

${ }^{22} \mathrm{~W}$ przytoczonym tekście widzimy wyraźny wpływ myśli starotestamentalnej, w której istniało głębokie przekonanie, że odwrócenie się od Boga pociągało za sobą - jako konsekwencje grzechu - choroby ciała i duchowe udręki człowieka. Mamy tu też interesujący przypadek wczesnochrześcijańskiej anatemy.

${ }^{23}$ Por. Joannes Chrysostomus, Expositio in Ps. 48, 4-5, PG 55, 228-229.

${ }^{24}$ Por. tenże, In epistulam I ad Corinthios hom. 15, 2, PG 61, 123-124.

${ }^{25}$ Por. tamże 39, 8, PG 61, 345. 
stopnia ciało jest „dostrojone” do duszy i jej potrzeb, bo przecież właśnie ono „zaślepia” duszę. Jan Chryzostom z łatwością wyjaśnia tę wątpliwość i tłumaczy, że to wcale nie ciało „zaślepia” duszę, lecz zbytek. To on jest „wrogiem”! i to nie tylko duszy, ale także ciała, które dobrze odżywione i przywiązane do dóbr materialnych staje się coraz mniej podatne na poruszenia duszy ${ }^{26}$.

3. Nieśmiertelność duszy. Nieśmiertelność duszy nie była kwestionowana ani w filozofii antycznej, ani w religii pogańskiej. Według św. Jana Chry-

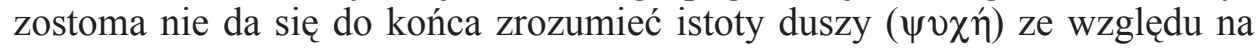
jej pozaczasowe istnienie i nieśmiertelność. Tłumaczy, że jeśli uszkodzimy jeden członek ciała, np. przez amputacją, to inne członki nie umrą i człowiek nadal żyje. Dusza nadal istnieje „w całości”, ale nie wiemy, w jaki sposób się to dzieje ${ }^{27}$. „W człowieku zaś dusza posiada naturę (ov̉oí $\alpha$ ) bezcielesną i nieśmiertelną i wielce przewyższa ciało"28. Zatem św. Jan Chryzostom również nie miał najmniejszych wątpliwości co do nieśmiertelności duszy. Podkreślał, że dusza jest nieśmiertelna nie z powodu własnej natury, jako niezrodzona i bez początku, ale ponieważ Bóg ,tchnął w nią” (por. Rdz 2, 7) ${ }^{29}$ i chciał, aby była nieśmiertelna - zatem dusza jest nieśmiertelna $\mathrm{z}$ woli Boga ${ }^{30}$. Tę nieśmiertelną duszę Bóg podarował człowiekowi, aby ten radował się wiecznym królestwem. W jednej z homilii na Ewangelię Jana Antiocheńczyk mówi, że istoty bezrozumne są pożyteczne jedynie w życiu doczesnym, natomiast człowiekowi została dana nieśmiertelna dusza, aby stał u boku króla na zawsze, przez całą wieczność ${ }^{31}$.

4. Pierwszeństwo duszy i jej godność. Główna przewaga duszy nad cia-

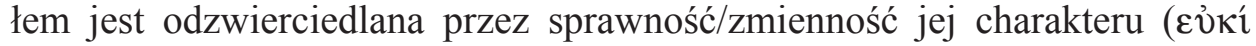

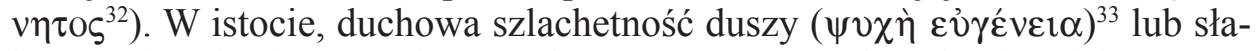
bość (, choroba duszy”) nie mogą być uważane za cechy właściwe jej z natury, natomiast fizyczne piękno/brzydota przynależy do ciała z natury i pozostaje niezbywalne, ponieważ cokolwiek przynależy do natury jest „,nieruchome

\footnotetext{
26 Por. tamże.
}

27 Por. tenże, De incomprehensibili Dei natura (Contra Anomoeos) hom. 5, 259-283, ed. A.-M. Malingrey, SCh 28bis, Paris 1970, 294.

${ }^{28}$ Tenże, In Genesim hom. 13, 3, PG 53, 107, tłum. własne.

${ }^{29}$ Por. tamże 12, 5, PG 53, 103.

${ }^{30}$ Por. tenże, In Joannem hom. 31, 5, PG 59, 182-184.

${ }^{31}$ Por. tamże.

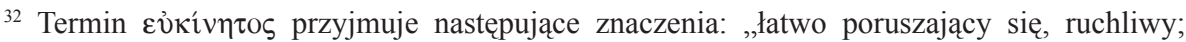

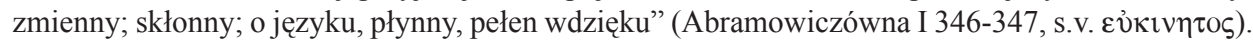

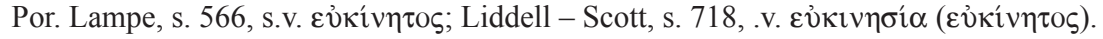

${ }^{33}$ Por. Joannes Chrysostomus, De fato et providentia or. 1, PG 50, 752; Quod nemo laeditur nisi a se ipso 5, PG 52, 465; De prohetiarum obscuritate hom. 2, 6, PG 56, 185; Expositio in Ps. 50(2), 5, PG 55, 580; 50(2), 9, PG 55, 585. 
i niezbywalne". W duszy łatwo może zajść każda zmiana, ponieważ to, co duchowe zależy od wolnej woli i intencji, a nie przynależy do natury. Jan Chryzostom wyjaśnia to zagadnienie w następujący sposób:

„Widzisz kochany, iż jest tu mowa o duszy. Naturalna brzydota ciała nigdy nie zmieni się w piękność, gdyż Pan uczynił naturę niezmienną. Jeśli zaś chodzi o duszę, jest to proste, a nawet bardzo łatwe. Dlaczego i w jaki sposób? To wszystko zależy od wolnej woli, a nie od natury Nawet bezkształtna i bardzo brzydka dusza, jeśli tylko zechce, może się przemienić, dojść do wielkiej piękności i stać się promienną. I przeciwnie: gdy się zaniedba, popadnie w wielką szpetotę. «Król zapragnie twej piękności» (Ps 45, 12), jeśli zapomnisz o dawnych czynach, «o twym ludzie, o domu - jak mówi - ojca twego» (Ps 45, 11)"34.

Stosując te prawdy w zakresie etycznym, Chryzostom zapewnia, że nie istnieje taka „choroba duszy”, która pozostawałaby nieuleczalna ${ }^{35}$, gdyż każda jej choroba da się wyleczyć właściwymi sobie lekarstwami. Dlatego Janowi Chryzostomowi wydaje się czymś dziwnym, że człowiek bardziej troszczy się o ciało i stara się nawet zmienić jego piękno (co w gruncie rzeczy jest niemożliwe), niż o duszę, którą może prowadzić do doskonałości, mimo tego, że poprawa jest $\mathrm{w}$ zasięgu jego rą $^{36}$. Z tego powodu złotousty kaznodzieja zdecydowanie nawołuje do zmiany ukierunkowania ludzkiej troski w taki sposób, aby była ona skoncentrowana na duszy:

„Będąc przeto pod panowaniem łaski, naśladujmy - proszę - przynajmniej teraz tych, którzy na własnym gruncie korzystając przed prawem ze złożonej w naturze nauki, do tak wysokiego stopnia cnoty się wznieśli i całą gorliwość skierujmy na potrzeby swej duszy. Zmieńmy swe starania i rozdzielmy swe troski! Na siebie weźmy potrzeby duszy, bo ona jest w nas istotna,

${ }^{34}$ Tenże, Catecheses ad illuminandos 1, 10, ed. A. Wenger, SCh 50bis, Paris 1970, 113-114, tłum. W. Kania, w: Św. Jan Chryzostom, Katechezy chrzcielne (homilie katechetyczne do tych, którzy maja być oświeceni oraz do neofitów, U źródeł katechumenatu 1, Lublin 1993, 25-26.

${ }^{35}$ Por. tenże, Ad Theodorum lapsum lib. 2, 16, ed. J. Dumortier, SCh 117, Paris 1966, 176-178, thum. W. Kania: Jan Chryzostom, Do Teodora po jego upadku, w: Św. Jan Chryzostom, O matzeństwie, wychowaniu dzieci i ascezie, BOK 19, Kraków 2000, 163.

${ }^{36}$ Por. tamże 2, 16, SCh 117, 176-178, BOK 19, 163: „Choć ciało cierpi często na nieuleczalną chorobę, nie tracimy nadziei $[\ldots]$, nie przestajemy na nich [tj. lekarzy] napierać, aby nas doprowadzili choć do małej ulgi. Jeśli chodzi o duszę, która nie może podlegać nieuleczalnej chorobie, jesteśmy beztroscy, jak gdyby to było obce nieszczęście, lub tracimy nadzieję. Gdzie natura choroby może nas wtrącić w beznadziejność, tak dokładamy starania, jak gdyby była wielka nadzieja wyzdrowienia; gdzie zaś nie ma żadnego powodu wattpienia, zaniedbujemy wszelkiej troski i poddajemy się zgubie, o wiele więcej troszcząc się o ciało niż o duszę. $Z$ tego powodu nie możemy nawet ciała uleczyć. Kto bowiem ważniejszą część zaniedbuje i cały trud obróci na mniejszą, ten obie zburzy i zepsuje. Kto zaś zachowuje porządek i ratuje ważniejszą, ten, choć się o drugie nie troszczy, już przez ratunek pierwszego pomaga również drugiemu". 
wspólnemu zaś Panu wszystkich pozostawmy troskę o sprawy ciała. To bowiem jest najlepszym dowodem Jego mądrości i niewypowiedzianej miłości, że troskę o ważniejszą rzecz, mianowicie o duszę, nam samym oddał w ręce, ucząc nas przez same sprawy, iż nas stworzył wolnymi, i naszej woli zostawił zarówno wybór cnoty, jak i unikanie złego, w potrzebach zaś ciała poprzyrzekł przyjść z pomocą"37.

5. Życie biologiczne a ,życie" duszy. Jan Chryzostom mówiąc o prawdziwym życiu, chce wykazać, że życie biologiczne ciała nie wyróżnia człowieka spośród innych istot żyjących, ani też nie jest cechą stanowiącą o byciu człowiekiem. Charakterystyczną cechą człowieka jest duchowa energia ( $̇$ vé $\gamma \varepsilon 1 \alpha^{38}$ ), co może być jedynie w pełni zrozumiane, gdy dusza jest otwarta na moc Ducha Świętego. Jan Chryzostom wprowadza rozróżnienie pomiędzy życiem biologicznym samym w sobie (jako oddzielnym istnieniem), a życiem człowieka, które obejmuje zarówno życie biologiczne, jak i życie duchowe - żywą duszę skłaniającą istotę ludzką do czynienia dobra i zdobywania cnoty. Chryzostom mówi, że o byciu człowiekiem żyjącym nie decyduje fakt, że oddycha i spogląda na otaczający go świat, ani nawet to, że używa rozumu, ale to, że wykorzystuje możliwości czynienia dobra oraz dba o wszystko, co dotyczy prawdziwego życia mającego nastąpić w przyszłości:

„Żywi różnią się od zmarłych nie tylko tym, że widzą słońce i oddychają powietrzem, nie tym powiadam, lecz tym, że czynią coś dobrego, bo gdyby tego nie było, w niczym nie byliby lepsi od umarłych"39.

„Zobaczmy czym jest człowiek. [...] Posłuchaj, co mówi [Pismo]: «Był człowiek sprawiedliwy, szczery, bogobojny, wstrzymujący się od wszelkiego złego uczynku» (Hi 1, 2. 8). To jest człowiek. A drugi znów mówi: «Wielka rzecz jest człowiek i rzecz cenna mąż miłosierny» (Prz 20, 6). Tych zaś, co nie są tacy, chociażby mieli uczestnictwo rozumu i chociażby tysiąc razy byli zdolni do wiedzy, Pismo zwykle nie nazywa ludźmi, lecz psami, końmi, żmijami, wężami, lisami, wilkami i co tam jeszcze jest podlejszego wśród zwierząt. Jeśli więc tym jest człowiek, to ten, który oddaje się zbytkom, nie

${ }^{37}$ Tenże, Catecheses ad illuminandos 8, 21-22, SCh 50bis, 258-259, thum. Kania, I, s. 117.

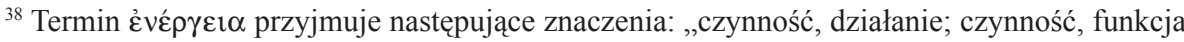
fizjologiczna; spełnienie; robota, wykonanie; oddziaływanie, skuteczność, o lekach; gram. strona czynna słowa; o stylu, żywość, obrazowość; filoz. aktualność" (Abramowiczówna II 137, s.v. Ėvé $\rho$ -

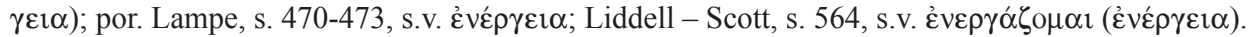

${ }^{39}$ Por. Joannes Chrysostomus, In epistulam I ad Timotheum hom. 13, 3-4, PG 62, 567, thum. T. Sinko, w: Św. Jan Złotousty, Homilie na Listy Pasterskie św. Pawła i na List do Filemona (Tym. I, II. Tyt. Filem.), Kraków 1949, 135. 
jest człowiekiem. Jakżeby bowiem był nim ten, który się nie troszczy o żadną z owych cnót?"40.

Złotousty kaznodzieja wyjaśnia, że doczesne życie biologiczne nie oznacza prawdziwego życia i wyjaśnia, że $\beta \imath \hat{\omega} v \propto \imath^{41}$ nie oznacza $\zeta \hat{\eta} v^{42}$. Życie nie może być mylone $\mathrm{z}$ byciem, a śmierć $\mathrm{z}$ niebytem ${ }^{43}$. Antiocheńczyk podkreśla, że Bóg stworzył świat z niczego i powołał stworzenie do istnienia zgodnie ze swoją wolą. Śmierć nie oznacza powrotu do nicości i nieistnienia ${ }^{44}$. Życie według Jana Chryzostoma jest dziełem cnoty, jest troską o prawdziwe życie, jest istnieniem żywej duszy. Jeśli bezużyteczne jest przykrywanie martwego ciała „kwiecistą szatą”, to i bezużyteczne jest też przykrywanie martwej duszy „kwitnącym ciałem”45. Z perspektywy eschatologicznej śmierć dosięga nie tylko ciała, ale i duszy. Śmierć duszy jest niebezpieczna, natomiast śmierć ciała może być pożyteczna, ponieważ prowadzi człowieka do miejsca jego przeznaczenia. Śmierć cielesna pochodzi od natury, a nie od woli, natomiast śmierć duchowa pochodzi od woli, a stanowi ją grzech ${ }^{46}$.

${ }^{40}$ Tamże 13, 4, PG 62, 569, thum. Sinko, s. 138.

${ }^{41}$ Termin $\beta \imath \hat{\omega} v \alpha \iota$ przyjmuje następujące znaczenia: „żyć, pędzić życie; wyżyć” (Abramowiczówna I 426, s.v. ßıó $\omega)$; por. Lampe, s. 298, s.v. ßıó $\omega$; Liddell - Scott, s. 316, s.v. ßıó $\omega$.

${ }^{42}$ Termin $\zeta \hat{\eta} v$ przyjmuje następujące znaczenia: „żyć, istnieć; pędzić życie, przeżywać, żyć

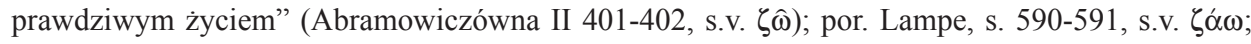
Liddell - Scott, s. 758 , s.v. $\zeta \hat{\omega}$.

${ }^{43}$ Por. Joannes Chrysostomus, In epistulam I ad Timotheum hom. 13, 3, PG 62, 567-568, thum. Sinko, s. 135-136: „Lecz żebyś to zrozumiał, zobaczmy, co jest dziełem żywych i co umarłych, i gdzie umieścimy tę zbytkującą [wdowę]? Żywi czynią rzeczy, odnoszące się do życia przyszłego, do życia prawdziwego. A co to są rzeczy przyszłego życia, o które należy nam się troszczyć w każdym czasie, o tym posłuchaj Chrystusa: «Pójdźcie, weźcie królestwo, zgotowane wam od założenia świata. Albowiem łaknąłem, a daliście mi jeść; pragnąłem, a napoiliście mię» (Mt 25, 34-35). [...] I abyś to zrozumiał, posłuchaj, jak i zmarły może żyć. [...] Umarłym jest za życia, kto żyje w zbytkach. W jaki sposób? Żyje tylko dla brzucha, a dla innych zmysłów wcale nie żyje”. Por. tenże, In Genesim hom. 37, 3, PG 53, 345; In epistulam I ad Corinthios hom. 17, 3, PG 61, 143; In epistulam ad Colosenses hom. 2, 6, PG 62, 318; De Lazaro con. 5, 3, PG 48, 1021.

${ }^{44}$ Por. tenże, In Genesim hom. 37, 3, PG 53, 345; In epistulam I ad Corinthios hom. 17, 3, PG 61, 143; In epistulam ad Colosenses hom. 2, 6, PG 62, 318; De Lazaro con. 5, 3, PG 48, 1021. Zob. A. Moulard, Saint Jean Chrysostome, sa vie, son oeuvre, Paris 1949, 123.

${ }^{45}$ Por. Joannes Chrysostomus, In epistulam I ad Timotheum hom. 13, 4, PG 62, 569, thum. Sinko, s. 137: „Jak martwemu ciału nic nie pomaga przywdziana kwiecista szata, tak i kwitnące ciało, otaczające martwą duszę, żadnego jej nie przynosi pożytku".

${ }^{46}$ Por. tamże 13, 4, PG 62, 569-572. Nie dziwi więc, że Chryzostom - idąc za nauczaniem Pisma Świętego - zauważa, że żywi, którzy umarli (por. 1Tm 5, 6) i umarli, którzy żyją (Abraham, Izaak; por. Mt 22, 32). Chryzostom mówi, że tylko ci, którzy praktykują cnotę naprawdę żyją, natomiast ci, którzy żyją w zbytku, już są martwi (tenże, In epistulam ad Romanos hom. 13, 7-8, PG 60, 517-520). Zob. tenże, In epistulam ad Romanos hom. 11, 5, PG 60, 489, tłum. Sinko, t. 1, s. 168 : „Różne są rodzaje martwoty. Jedna jest śmiercią ciała, według której Abraham choć umarł, nie był umarły. «Bóg bowiem», powiada [Pismo], «nie jest Bogiem umarłych, lecz żyjących» (Mt 22, 32), 
6. Ciało i duch w kontekście zmagań duchowych. Człowiek, który chce odpowiednio karmić swą duszę i żyć w pobożności, narażony jest na ataki złego ducha, który chce wzbudzić w duszy ludzkiej różnego rodzaju pożądania cielesne. Dlatego św. Paweł mówi, że „,ciało do czego innego dąży niż duch, a duch do czego innego niż ciało, i stąd nie ma między nimi zgody" (Ga 5, $17)^{47}$. Według Chryzostoma człowiek właściwie odżywiający swą duszę musi w życiu kierować się prawdziwą filozofią, czyli zasadami przedstawionymi przez Chrystusa w Ewangelii. Sprowadzają się one do unikania zbytku i praktykowania ascezy oraz umartwiania ciała, zgodnie z wyznaniem Apostoła Narodów: ,poskramiam moje ciało i biorę je w niewolę” (1Kor 9, 27), który czyni aluzję do trudności, jakie spotkają tych, którzy ujarzmiają swoje ciała ${ }^{48}$. Jednak tylko przez ,poskramianie” ciała - wyniszczania „człowieka zewnętrznego” wzmacnia się i wzrasta „człowiek wewnętrzny” (por. 2Kor 4, 16) ${ }^{49}$.

Chryzostom analizując wypowiedź św. Pawła z Listu do Galatów $(5,17)$ informuje, że w jego czasach niektórzy niewłaściwie ją rozumieją, twierdząc, że Paweł dzieli człowieka na dwie przeciwstawne sobie istoty, wykazując tym samym, że dusza prowadzi wojnę z ciałem. Jednak - jak podkreśla Antiocheńczyk - nie jest to prawda, gdyż Paweł Apostoł „ciałem nie nazywa rzeczywistego ciała", ponieważ członki ciała nie są rozważane w kategorii czynników

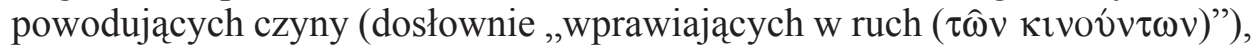
ale w kategorii elementów, na których czynność jest wykonywana (dosłownie

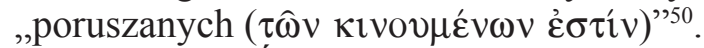

W Piśmie Świętym „ciało” nie oznacza zewnętrznej ludzkiej powłoki. W istocie, św. Jan Chryzostom wypowiadając się na ten temat zauważa, że św. Paweł „ciałem nazywa nie ciało fizyczne, lecz złą wolę"51. Z drugiej strony - kontynuuje swe rozważania - Paweł Apostoł mówi: „«Wy nie jesteście w ciele, lecz w duchu» $(\mathrm{Rz} 8,9)$ lub «Ci, którzy są w ciele, nie mogą się podobać Bogu» $(\mathrm{Rz} 8,8)$ "`2. Zgodnie z interpretacją św. Jana Chryzostoma,

Druga - śmiercią duszy, o której Chrystus mówi zagadkowo: «Zostaw umarłym grzebanie ich umarłych» (Mt 8, 22; Łk 9, 60)"; In epistulam ad Ephesios hom. 4, 1, PG 62, 31.

${ }^{47}$ Por. tenże, De Lazaro con. 3, 6, PG 48, 1000.

${ }^{48}$ Por. tamże.

${ }^{49}$ Por. tenże, In epistulam ad Ephesios hom. 13, 2, PG 62, 95-96.

${ }^{50}$ Por. tenże, In epistulam ad Galatas comm. 5, 5, PG 62, 671, thum. J. Iluk: Jan Chryzostom, Komentarz do Listu św. Pawła do Galatów, ŹMT 47, Kraków 2008, 121: „Za sprawą tych słów [Ga $5,17]$, niektórzy nas atakują, twierdząc, że apostoł rozdzielił człowieka na dwie części, przedstawiając go niejako złożonego z dwóch wrogich sobie bytów, czyli: że ciało prowadzi walkę z duszą. Wszelako, nie jest tak. O, nie. [Paweł] ciałem nie nazywa rzeczywistego ciała; gdyby tak miało być, to jaki sens ma późniejsze stwierdzenie: «pożąda przeciwko Duchowi». Nasze ciało nie wprawia w ruch, ale należy do rzeczy poruszanych; nie jest siłą sprawczą, ale podlega takiej sile. Jakże więc ma pożądać, skoro pożądanie pochodzi z duszy, a nie z ciała". Zob. tenże, In epistulam ad Romanos hom. 12, 4, PG 60, 499; 13, 2, PG 60, 509.

${ }^{51}$ Tenże, In epistulam ad Galatas comm. 5, 5, PG 62, 671, ŹMT 47, 122.

${ }^{52}$ Tamże. 
Paweł Apostoł nie ma na myśli tego, że powinno się zniszczyć ciało (taka interpretacja jest wynikiem podszeptu diabelskiego). W rzeczywistości „ciało” oznacza „ziemską myśl”, a odpowiedzialność za taką myśl nie może być przypisana ciału, lecz „leniwej duszy”, „gdyż ciało jest jej narzędziem”53. Paweł Apostoł mówi:

„Jest zaś rzeczą wiadomą, jakie uczynki rodzą się z ciała: nierząd, nieczystość, wyuzdanie, uprawianie bałwochwalstwa, czary, nienawiść, spór, zawiść, wzburzenie, niewłaściwa pogoń za zaszczytami, niezgoda, rozłamy, zazdrość, pijaństwo, hulanki i tym podobne" (Ga 5, 19-21).

Wprawdzie niektóre z wyżej wymienionych przez Pawła grzechów można by uznać za grzechy „ciała” (np. nierząd, nieczystość, wyuzdanie), jednak zdecydowanej większości grzechów z powyższego katalogu nie można przypisać „ciału” (np. nienawiść, zawiść, niezgoda, zazdrość). Oczywistym jest zatem, że Paweł Apostoł używa terminu „,ciało” przede wszystkim na oznaczenie przyziemnych, „cielesnych” trosk człowieka, a nie na oznaczenie cielesnej powłoki człowieka. W konsekwencji, określanie przyziemnej troski słowem „ciało” nie może być uważane za wyrzut w stosunku do cielesnej powłoki ${ }^{54}$.

$$
* * *
$$

W podsumowaniu należy zauważyć, że św. Jan Chryzostom w nauczaniu na temat człowieka rozumie słowo ,duch" nie jako żyjącą duszę, to znaczy duchowy element człowieka, ale jako „Ducha Świętego”, oczywiście bez ujmowania niczego roli duszy. W konsekwencji, walka pomiędzy ciałem a duchem oznacza walkę pomiędzy przyziemną troską, wynikającą z niewłaściwych pragnień duszy spowodowanych przez złego ducha i Duchem Świętym, który jest dawcą życia. W każdym razie, nie jest to ontologiczna walka pomiędzy ciałem i dusza, ale moralna walka życia i śmierci. W tym względzie św. Jan Chryzostom mówi, że wrogość duszy wobec ciała jest po prostu wrogością zła wobec cnoty, co w rzeczywistości oznacza walkę pomiędzy żyjącą (dążącą do cnoty) a martwą (pogrążoną w nieprawości) duszą.

\footnotetext{
${ }^{53}$ Tamże.

${ }^{54}$ Por. tenże, In epistulam I ad Corinthios hom. 42, 1, PG 61, 361.
} 


\section{IF THE SOUL STRUGGLING WITH THE BODY? SELECTED ASPECTS OF ANTHROPOLOGY OF ST. JOHN CHRYSOSTOM}

\section{(Summary)}

This article takes the fight of the soul with the body and presents selected items of anthropology of St. John Chrysostom. John Chrysostom examines the human situation after original sin in the eschatological aspect and indicates that the body is not the cause of evil, because sin is the consequence of free choice man. Then presents the relationship between the body and the soul, and stresses that the body is subordinate to the soul, to whom falls the responsibility for the deeds of the body. The soul is immortal by the will of God and his dignity transcends the body. The Preacher explains that the worldly biological life doesn't mean real life. John Chrysostom in teaching on man understands the word "spirit" not as a living soul, that is to say, the spiritual element of the man, but as the „Holy Spirit", of course, without the recognition of the role of anything of the soul. Consequently, the struggle between body and spirit means the fight between earthy concern resulting from the inappropriate desires of the soul caused by an evil spirit, and the Holy Spirit, who is the giver of life. This is not the ontological fight between body and soul, but the moral struggle of life and death. In this respect, John Chrysostom says, that the hostility of the soul to the body is simply hostility of evil to the virtues, which in fact means the fight between the living (which aims to virtue) and the dead (in the broad people's iniquity) soul.

Key words: John Chrysostom, anthropology, soul, body, spiritual warfare.

Słowa kluczowe: Jan Chryzostom, antropologia, dusza, ciało, walka duchowa. 
